\title{
Market Concentration and Risk-Taking in Banking Sector Listed on Indonesian Stock Exchange
}

\author{
Elliv Hidayatul Lailiyah, Ika Purwanti, Umar Yeni Suyanto \\ Department of Management, Institut Teknologi dan Bisnis Ahmad Dahlan Lamongan, \\ Jalan KH. Ahmad Dahlan No.41, Lamongan, Jawa Timur, 62115
}

\section{ARTICLE INFO \\ Keywords: \\ Market concentration, Risk-Taking, \\ Bank Size. \\ Kata Kunci: Konsentrasi pasar, Mengambil resiko, Ukuran Bank.}

\section{A B S T R A C T}

The financial institution roles as the bank credit distribution. According to the banking surveys in Indonesia, it indicates that new credit growth has been strengthened. The increasing of credit leds to increase the level of risk taking by banks that its concentration of banking in a country plays in influencing banking risk taking. This study examined the effect of banking market concentration on bank risk taking. It also explored the moderating variable of bank size on the effect of market concentration on risk taking in the banking sector. The results of the study showed that the banking market concentration has the positive effect on banking risk taking. The size of the bank weakens the positive effect of market concentration on bank risk taking. The larger the size of the bank in a concentrated banking market, the lower the risk taking of the bank. The concentrated banking market requires to distribute the market share in banks to be carried out by banking regulators so that the banking market is not concentrated and reduces banking risk taking.

\section{SARI PATI}

Bank berperan sebagai lembaga pembiayaan keuangan melalui penyaluran kredit bank. Hasil survei perbankan di Indonesia menunjukkan bahwa pertumbuhan kredit baru mengalami penguatan. Adanya peningkatan kredit yang signifikan ini menyebabkan tingkat pengambilan risiko oleh bank juga semakin meningkat. Konsentrasi perbankan disuatu negara berperan dalam mempengaruhi pengambilan risiko perbankan. Penelitian ini menguji pengaruh konsentrasi pasar perbankan terhadap pengambilan risiko bank. Penelitian ini juga menguji efek moderasi ukuran bank pada pengaruh konsentrasi pasar terhadap pengambilan risiko pada sektor perbankan. Hasil penelitian menunjukkan bahwa Konsentrasi pasar perbankan berpengaruh positif terhadap pengambilan risiko perbankan. Ukuran bank memperlemah pengaruh positif konsentrasi pasar terhadap pengambilan risiko bank. Semakin besar ukuran bank pada pasar perbankan yang terkonsentrasi, maka pengambilan risiko bank akan semakin rendah. Pasar perbankan yang terkonsentrasi mengharuskan 
penyebaran pangsa pasar pada perbankan perlu dilakukan oleh regulator perbankan agar pasar perbankan tidak terkonsentrasi dan mengurangi pengambilan risiko perbankan.

(C) 2020 IRJBS, All rights reserved.

\section{INTRODUCTION}

The Law of the Republic of Indonesia Number 10 of 1998 states that banks are business entities that collect funds from the public in the form of deposits and distribute them to the public in the form of credit and or other forms in order to improve the lives of many people. The bank acts as an intermediary institution that connects the underfunded party with the excess funds. The role of banks in managing assets is inseparable from the risk taking of the assets being managed.

Banks play an important role in the economy because banks are intermediary institutions, namely as intermediaries between those who need funds and those who are excess funds. The bank acts as a financial financing institution through bank lending. This bank credit can help economic actors in carrying out national economic activities. Therefore, bank credit is a very necessary thing especially for business people to start or develop their business.

The results of a banking survey conducted by Bank Indonesia indicate that new credit growth has strengthened. This indication is reflected in the Weighted Net Balance (SBT) of new credit requests which increased from 21.7 percent in the first quarter of 2014 to 70.6 percent in the fourth quarter of 2019 (Bank Indonesia, 2020). The upward trend was also shown by the domestic credit to private sector (\% of GDP) in Indonesia which is domestic credit for the private sector that refers to financial resources provided to the private sector such as through loans. Based on the World Bank (2019) it was reported that the domestic credit to private sector (\% of GDP) in Indonesia amounted to 33.4 in 2012 , an increase of 38.8 in 2018.
The existence of a significant increase in credit causes the level of risk taking by banks to increase. Delis \& Kouretas, (2011) explained that bank risk taking is a condition in which a bank increases its risk assets i.e. all bank assets can change in value due to changes in market conditions or changes in credit quality on various payment opportunities. This means that an increase in risky assets can indicate a more risky bank position. One of the risk assets in the banking sector is non-performing loans. Nonperforming loans are loans that have the potential to fail pay.

Risk taking in the banking sector is measured by Non Performing Loans (NPLs). NPLs reflect the quality of bank assets, namely the potential for adverse exposure to income and market value of assets due to declining credit quality. In other words, NPL is a credit risk. The higher the NPL value, the more risky a credit will be.

Tabak, et al (2013) argue that banking concentration in a country plays a role in influencing banking risk taking. (Milind (2008) in his research suggested that concentration refers to the level of control of economic activity by large companies. With regard to the banking sector, the concentration of the banking market can be interpreted that control of the banking market share is carried out by several large banks. This is because the number of large banks is less when compared to the number of small banks. In other words, this condition will form an oligopoly market, a market where the supply of a type of goods, in this case the banking sector, is only controlled by a few companies. Whereas (Tabak et al., 2013) argue that market concentration can be 
interpreted that there are a number of dominant banks and many banks of small size that are related in a market.

Measurement of banking market concentration in this study follows the research of Tabak et al., (2013), Alhassan, et al.(2016) and Barra \& Zotti, (2019) using the Herfindahl Hirschman Index (HHI). The value of $\mathrm{HHI}$ is between 0 and 1 . The greater the value of $\mathrm{HHI}$ (close to number 1), it can be said that the market will be more concentrated. The higher the level of market concentration, the lower the level of competition. And vice versa, the smaller the value of $\mathrm{HHI}$ (approaching 0 ) the lower the market concentration so that competition will be higher.

The banking conditions described above are in accordance with the real conditions in Indonesia. Based on the Indonesian Banking Statistics (SPI) issued by the Financial Services Authority (OJK) as of July 2019, in recording the total assets of the Commercial Bank Business Group (BUKU) IV category with capital above Rp 30 trillion, it has reached 4,396.67 trillion. The amount represents $53.23 \%$ of total banking assets in industry which reached Rp 8,258.88 trillion in the end of July 2019 (Kompas, 2019). There are many banks that run operations in Indonesia, but based on total assets there are only six large banks that control the banking market share in Indonesia, namely Bank Rakyat Indonesia (BRI), Bank Mandiri, Bank Central Asia (BCA), Bank Negara Indonesia (BNI), Bank CIMB Niaga and Bank Panin. The other bank are banks with small asset sizes.

Several previous studies have shown empirical evidence regarding the effect of banking concentration on bank risk taking. Banks will dare to take high risks to get high profits when the banking market has a high level of concentration.

De Nicoló, et.al (2006) in his study in the US in the period 1993-2004 and supported by the research of De Nicoló \& Loukoianova (2007) found that there was a positive influence between banking concentration and banking risk. Research Beck, et.al (2006) also support that banking concentration has a positive effect on bank decision making. This means that the more concentrated a bank will increase risk taking. Market strength or high market concentration in the loan market will increase the risk of banking or non-performing loans (Berger, at.al, 2017). Tan \& Floros, (2014) in his research in China in the period 2003 to 2013 proved that the high level of competition in a concentrated market led to high credit risk. In addition, Tan \& Floros (2014) also explained that banks in China that have high credit risk have low cost efficiency.

Banking size can be interpreted as the total value of assets owned by a bank. The greater the total assets, the greater the size of the bank. Tabak et al., (2013) argues that the greater the size of a bank, the bank has the ability to absorb funding sources in the form of larger third party funds, so as to provide higher efficiency. Because the total assets of a bank have a large nominal, this study uses the natural log of total bank assets to measure banking size.

Tabak et al., (2013) in his research examines bank size and market concentration on performance and risk. Research of Tabak et al., (2013) was conducted in Latin America in 2001-2008. The results showed that large banks will weaken the positive influence between market concentration on bank risk taking. Louzis,et.al (2012) argues that large banks are able to provide low credit costs because they can increase efficiency, so that large banks can attract more borrowers without having to relax credit terms that can increase the risk of bad credit, and ultimately will increase bank profitability. This is reinforced by research by Koetter, et.al (2012) that there is a positive relationship between market power or market concentration and cost efficiency.

Different things were found in other studies namely Altunbas, et.al (2007) and Cihák, et al. (2006) who found that there was no relationship between market concentration and risk taking. Altunbas et al., (2007) and Cihák et al., (2006) argued that low concentration will not increase risk instability. 
Based on the background of the problems that have been described and the differences in the results of previous studies, this study aims to determine the effect of market concentration on risk taking in the banking sector. In addition, this study also aims to determine the effect of bank size moderation on the influence of market concentration on risk taking in the banking sector.

\section{METHODS}

This type of research is explanatory with a quantitative approach. The sample is determined by the purposive sampling method with certain criteria, namely conventional commercial banks listed on the Indonesia Stock Exchange in 20132018. Secondary data in the form of annual reports and financial reports are collected through the Indonesia Stock Exchange website and the official website of the relevant bank. Samples were 214 observations. The stages of data analysis are by counting all the variables studied, conducting a classic assumption test, conducting a regression test with SPSS software, and testing a hypothesis. Table 1 is a measurement of the variables used in this study.

Tabel 1. Variable Measurement

\section{Variable} Measurement

$1 \quad$ Bank Risk-Taking proxied by NPL Market Concentration proxied by HHI

$\mathrm{HHI}_{\mathrm{t}}=\sum_{\mathrm{i}=1}^{\mathrm{N}}\left(\frac{\text { Total Asset }_{\mathrm{i}, \mathrm{t}}}{\text { Total Asset all bank }_{\mathrm{t}}}\right)^{2}$

$3 \quad$ Bank Size

Source: Various journals and literature

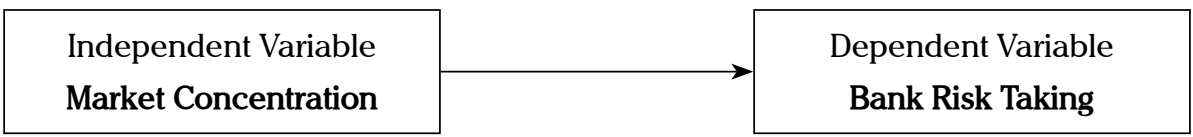

Figure 1. Conceptual framework (model I)

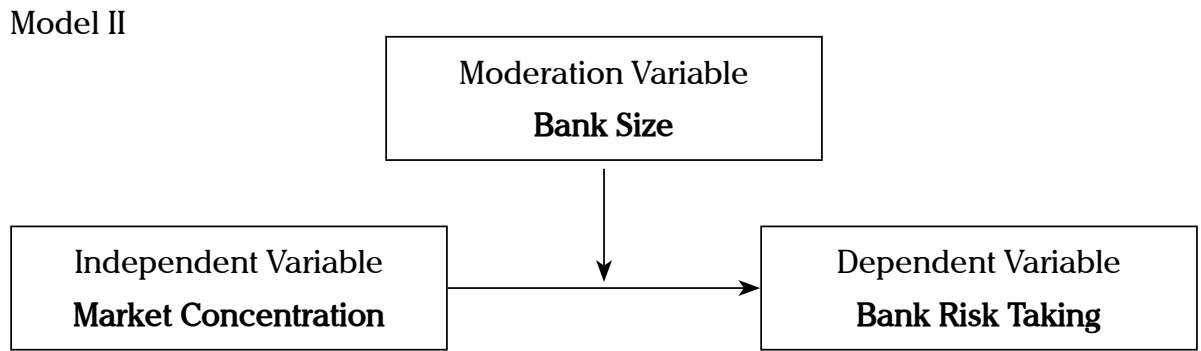

Figure 2. Conceptual framework (model II) 
Based on the problem formulation and research objectives, model I can be illustrated in the conceptual framework of figure 1 , that is the effect of market concentration on bank risk taking. Whereas in figure 2 is the conceptual framework of model II, which is the influence of market concentration on bank risk taking moderated by bank size.

The hypotheses in this study are as follows:

H1 = Market concentration has a positive effect on bank risk taking

H2 = Large bank size weakens the positive influence of market concentration on bank risk taking.

Based on the hypotheses, the analysis model in this study can be write as follows:

$\mathrm{RISK}_{\mathrm{i}, \mathrm{t}}=\alpha_{0 \mathrm{it}}+\beta_{1} \mathrm{HHI}_{\mathrm{it}}+\varepsilon_{\mathrm{it}}$

$\operatorname{RISK}_{\mathrm{i}, \mathrm{t}}=\alpha_{0 \mathrm{it}}+\beta_{1} \mathrm{HHI}_{\mathrm{it}}+\beta_{2} \mathrm{SIZE}_{\mathrm{it}}+\beta_{3 \mathrm{it}} \mathrm{HHI} * \mathrm{SIZE}+\varepsilon_{\mathrm{it}}$

\section{RESULTS AND DISCUSSION}

In this study, the classical assumption test has been performed and has met the four classic assumption tests. The result of test are normally distributed data, the data does not contain multicollinearity, there is no heterokedastisitas and there is no autocorrelation.
Based on table 2, the average RISK variable that is proxied by NPL is 0.0251 or $2.51 \%$ with a standard deviation of 0.0139 . The value of the standard deviation is smaller than the average. This shows that the level of data diversity or NPL variability is quite low. The maximum value of NPL 0.0611 shows that banks have high risk taking. The minimum value of NPL 0.0005 indicates that the bank has a low risk taking.

The average market concentration proxied by the Herfindal Hirschman Index (HHI) is 0.1087 with a standard deviation of 0.0026 . The standard deviation value is smaller than the average HHI. This shows that the level of diversity of data or variability of $\mathrm{HHI}$ is quite low. The maximum value of $\mathrm{HHI}$ of 0.1112 indicates that the concentration of the banking market in Indonesia is high.

The average bank size (SIZE) is 31,100 with a standard deviation of 1.8141. The standard deviation is smaller than the average SIZE. This shows that the level of data diversity or SIZE variability is quite low. The maximum value of SIZE is 34.6834 which shows that the bank has a large total assets. The minimum SIZE value of 27.3380 indicates that the bank has a small total asset.

Tabel 2. Descriptive statistics

\begin{tabular}{|c|c|c|c|c|c|}
\hline Variable & $\mathrm{N}$ & Min & Max & Mean & Std.Dev. \\
\hline$\overline{\text { RISK }}$ & 214 & 0.0005 & 0.0611 & 0.0251 & 0.0139 \\
\hline $\mathrm{HHI}$ & 214 & 0.1034 & 0.1112 & 0.1087 & 0.0026 \\
\hline SIZE & 214 & 27.3380 & 34.6834 & 31.1100 & 1.8141 \\
\hline
\end{tabular}

Source: Data processed

Tabel 3. Regression analysis results

\begin{tabular}{lcc}
\hline & (Model 1) & (Model 2) \\
& RISK & RISK \\
\hline HHI & 1.136 & 1.598 \\
& $(0.002)^{*}$ & $(0.000)^{*}$ \\
SIZE & & 0.002 \\
& & $(0.003)^{*}$ \\
HHI*SIZE & & -0.016 \\
& & $(0.041)^{* *}$ \\
\hline
\end{tabular}

* significant at $1 \%$, ** significant at $5 \%$

Source: Data processed 
Effect of market concentration on bank risk taking The first model in this study uses linear regression to examine the effect of market concentration on bank risk taking. Based on table 3 the results of regression tests using SPSS, show that the banking market concentration (HHI) variable has a significant positive effect on bank risk taking (RISK). The significance value of $\mathrm{HHI}<0.01$, then $\mathrm{H}_{0}$ is rejected and $\mathrm{H}_{1}$ is accepted. This means that the higher the market concentration in the banking sector, the higher the risk taking by banks.

The results of this study support the research of Tabak et.al. (2012) that a concentrated market will create competition that has an impact on risk taking. This research shows that there is a positive influence of market concentration on risk taking. The positive effect that occurs is because there is market control by several large banks that form an oligopoly market in banks.

Milind (2008) argues that the oligopoly banking market condition is because there are several banks that dominate the market and others are small banks with a small market share. This is happened in Indonesia, where only a few large banks controlled the banking market share. Some previous research states that in a concentrated banking market, concentrated banks will obtain higher profits (Hellmann et.al, 2000; Salas \& Saurina, 2003; Allen \& Gale, 2004; Jeon, \& Miller, 2005; Jiménez \& Lopez, 2010; Barra \& Zotti, 2019)

Conversely, different things happen to small banks. Small banks are not able to produce high profitability because the market share has been controlled by large banks. This is due to the low ability of small banks to collect third party funds. The solution, small banks will increase their risk assets to be able to generate profits. The ease of taking credit is used by small banks as a solution to get profit. The ease of taking credit can increase the risk in the banking world. So it can be concluded that the higher the concentration of the banking market, the higher the risk taking by banks. This supports research from Tabak et al., (2013). This is also reinforced by De Nicoló et al., (2006) research that concentration can increase systematic risk through high borrower costs.

\section{The effect of market concentration on bank risk taking moderated by bank size}

The second model in this study includes a moderating variable that is the size of the bank. Based on table 3 , the results of regression tests using SPSS, show that the banking market concentration (HHI) variable has a significant positive effect on bank risk taking (RISK). The significance value of $\mathrm{HHI}<0.01$, then $\mathrm{H}_{0}$ is rejected and $\mathrm{H}_{1}$ is accepted. This means that the higher the market concentration in the banking sector, the higher the risk taking by banks.

The results of interactions between the market concentration and banking size variables (HHI * SIZE) show a significant negative sign with a significance value $<0.05$, so that $\mathrm{H}_{0}$ is rejected and $\mathrm{H}_{1}$ is accepted. This means that banking size weakens the positive influence of market concentration on bank risk taking. In other words, the positive effect of the concentration of the banking market on bank risk taking will be even weaker at large banks.

The results of this study support the research of Tabak et al., (2012)that a large size of a bank will provide benefits in a competitive market or in a concentrated market. Banks with large size are more capable in obtaining third party funds even with small interest costs. Because large banks find it easier to get third-party funds, large banks in lending can also provide lower interest rates compared to smaller banks. This is a cost efficiency in obtaining third party funds and channeling credit. The cost efficiency generated by these large banks which affect the positive influence of the banking market concentration on bank risk taking becomes increasingly weak (Tabak et al., 2013).

In addition to cost efficiency, it can also be seen from the lower level of risk. Many borrowers will 
be interested in doing credit because banks provide lower credit costs. The large number of borrowers will increase the bank profitability. Large banks do not have to relax credit terms because loose credit conditions increase bank risk.

Zhang, et.al, (2013) in their study stated that banks would improve their performance by reducing credit risk and overall risk from banks. So it can be said that banks with large size will reduce risk taking. In conclusion, the increasingly concentrated condition of the banking market will increase bank risk taking because many small banks will do various ways to get third-party funds including by loosening credit conditions, but the increasingly large bank size are able to play a role in weakening the positive influence of the concentration of the banking market on risk-taking bank. This is because large banks will still be in great demand without having to loosen credit terms.

\section{MANAGERIAL IMPLICATION}

The adverse impact of high banking risk taking on a concentrated banking market requires that the distribution of market share in the banking sector needs to be done by the banking regulator so that the banking market is not concentrated and reduces banking risk taking.

\section{CONCLUSION}

The concentration of the banking market has a significant positive effect on bank risk taking. This means that the higher the market concentration in the banking sector, the higher the risk taking by banks. Bank size weakens the positive effect of market concentration on bank risk taking. In other words, the greater the size of the bank in a concentrated banking market, the lower the risktaking of banks..

\section{REFERENCES}

Alhassan, A. L., Tetteh, M. L., \& Brobbey, F. O. (2016). Market power, efficiency and bank profitability: evidence from Ghana. Economic Change and Restructuring. https://doi.org/10.1007/s10644-015-9174-6

Allen, F., \& Gale, D. (2004). Competition and Financial Stability. Journal of Money, Credit, and Banking. https://doi.org/10.1353/ mcb.2004.0038

Altunbas, Y., Carbo, S., Gardener, E. P. M., \& Molyneux, P. (2007). Examining the relationships between capital, risk and efficiency in European banking. European Financial Management. https://doi.org/10.1111/j.1468-036X.2006.00285.x

Barra, C., \& Zotti, R. (2019). Bank Performance, Financial Stability And Market Concentration: Evidence From Cooperative And Non-Cooperative Banks. Annals of Public and Cooperative Economics. https://doi.org/10.1111/apce.12217

Beck, T., Demirgüç-Kunt, A., \& Levine, R. (2006). Bank concentration, competition, and crises: First results. Journal of Banking and Finance. https://doi.org/10.1016/j.jbankfin.2005.05.010

Berger, A. N., Klapper, L. F., \& Turk-Ariss, R. (2017). Bank competition and financial stability. In Handbook of Competition in Banking and Finance. https://doi.org/10.4337/9781785363306.00018

Cihák, M., Wolfe, S., \& Schaeck, K. (2006). Are More Competitive Banking Systems More Stable? IMF Working Papers. https:// doi.org/10.5089/9781451864038.001

De Nicoló, G., Jalal, A. M., \& Boyd, J. H. (2006). Bank Risk-Taking and Competition Revisited: New Theory and New Evidence. IMF Working Papers. https://doi.org/10.5089/9781451865578.001

De Nicoló, G., \& Loukoianova, E. (2007). Bank Ownership, Market Structure and Risk. IMF Working Papers. https://doi. org/10.5089/9781451867794.001 
Delis, M. D., \& Kouretas, G. P. (2011). Interest rates and bank risk-taking. Journal of Banking and Finance. https://doi. org/10.1016/j.jbankfin.2010.09.032

Hellmann, T. F., Murdock, K. C., \& Stiglitz, J. E. (2000). Liberalization, moral hazard in banking, and prudential regulation: Are capital requirements enough? American Economic Review. https://doi.org/10.1257/aer.90.1.147

Jeon, Y., Miller, S. M., \& Miller, S. M. (2005). Bank Performance : Market Power or Efficient Structure ? Department of Economics Working Paper Series. Central Michigan University.

Jiménez, G., \& Lopez, J. a. (2010). How Does Competition Impact Bank Risk-Taking ? How Does Competition Impact Bank Risk-Taking ? Supervision. https://doi.org/10.2139/ssrn.1582331

Koetter, M., Kolari, J. W., \& Spierdijk, L. (2012). Enjoying the quiet life under deregulation? Evidence from adjusted lerner indices for U.S. banks. Review of Economics and Statistics. https://doi.org/10.1162/REST_a_00155

Louzis, D. P., Vouldis, A. T., \& Metaxas, V. L. (2012). Macroeconomic and bank-specific determinants of non-performing loans in Greece: A comparative study of mortgage, business and consumer loan portfolios. Journal of Banking and Finance. https://doi.org/10.1016/j.jbankfin.2011.10.012

Milind Sathye. (2008). The Impact of Foreign Banks on Market Concentration: The Case of India. Applied Econometrics and International Development, 2(1), 7-20.

Salas, V., \& Saurina, J. (2003). Deregulation, market power and risk behaviour in Spanish banks. European Economic Review. https://doi.org/10.1016/S0014-2921(02)00230-1

Tabak, B. M., Fazio, D. M., \& Cajueiro, D. O. (2012). The relationship between banking market competition and risk-taking: Do size and capitalization matter? Journal of Banking and Finance. https://doi.org/10.1016/j.jbankfin.2012.07.022

Tabak, B. M., Fazio, D. M., \& Cajueiro, D. O. (2013). Systemically important banks and financial stability: The case of Latin America. Journal of Banking and Finance. https://doi.org/10.1016/j.jbankfin.2013.06.003

Tan, Y., \& Floros, C. (2014). Risk, Profitability, and Competition: Evidence from the Chinese Banking Industry. The Journal of Developing Areas. https://doi.org/10.1353/jda.2014.0054

Zhang, J., Jiang, C., Qu, B., \& Wang, P. (2013). Market concentration, risk-taking, and bank performance: Evidence from emerging economies. International Review of Financial Analysis. https://doi.org/10.1016/j.irfa.2013.07.016

Bank Indonesia. Survei Perbankan Triwulan IV-2019. (Online) https:/www.bi.go.id/id/publikasi/survei/perbankan/Pages/SP_ TW4_2019.aspx. Accessed February 20, 2020

Kompas.com. 6 Bank Besar Kuasai 53 Persen Aset Perbankan Indonesia, Siapa Saja?. (online), https://money.kompas.com/ read/2019/10/15/071100126/6-bank-besar-kuasai-53-persen-aset-perbankan-indonesia-siapa-saja-?page=all. Accessed February 20, 2020

Otoritas Jasa Keuangan. Statistik Perbankan Indonesia. (Online). https:/www.ojk.go.id/id/kanal/perbankan/data-dan-statistik/ statistik-perbankan-indonesia/Pages/Statistik-Perbankan-Indonesia---Juli-2019.aspx. Accessed February 20, 2020

Undang-Undang Nomor 10 Tahun 1998. Tentang Perubahan Atas Undang-Undang Nomor 7 Tahun 1992 Tentang Perbankan. https://www.bphn.go.id/data/documents/98uu010.pdf. Accessed February 20, 2020

World Bank. Domestic credit to private sector (\% of GDP)- Indonesia. (Online) https://data.worldbank.org/indicator/FS.AST. PRVT.GD.ZS?end=2018\&locations $=$ ID\&start $=1980$. Accessed February 20, 2020. 